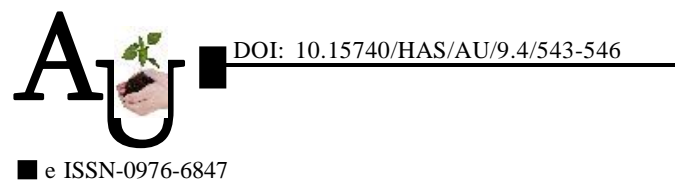

Research Article

\title{
Training needs of agricultural input dealers in transfer of agriculture technology in Ratnagiri district of Konkan region
}

\author{
Y.J. WAGHMODE, A.N. DESAI AND P.A. SAWANT
}

Article Chronicle : Received :

15.09.2014;

Revised :

01.10.2014;

Accepted :

13.10.2014

\section{KeY WoRds:}

Training need, Knowledge, Transfer of technology
SUMMARY : Training need is essential to induce knowledge and skills of any agricultural input dealers about Transfer of Agriculture Technology. The present study was, therefore, designed to ascertain the training needs of agriculture input dealers. The research study was carried out in 9 tahsils of Ratnagiri district in Konkan region of Maharashtra State during 2011-2012. Result of this study revealed that majority (66.67\%) of the respondents had 'medium' training need on various aspects of fertilizer, seed, pesticides, machinery and implements, animal feed and chemicals and their use While 18.66 per cent of the respondents had 'more' training need followed by 14.67 per cent of the respondents had 'low' training need. Similarly in case of the various aspects wise training need of the agriculture input dealers it was observed that there were various areas of agriculture input dealers required training need like that 'business management' (88.00\%), 'integrated nutrient management' $(78.67 \%)$, 'improved varieties and hybrids of different crops' (57.33\%), 'efficient use of information technology' (56.00\%), also (49.33\%) the agricultural input dealers from region had expressed 'most needed' training needs on 'micro nutrient fertilizers' and 'information communication technology' $(48.00 \%)$. Hence, the study imply that the extension functionaries should arrange training programme and cover the above explained training need areas for agriculture input dealers, that will also help for improving knowledge and communication of transfer of agriculture technology.

How to cite this article : Waghmode, Y.J., Desai, A.N. and Sawant, P.A. (2014). Training needs of agricultural input dealers in transfer of agriculture technology in Ratnagiri district of Konkan region. Agric. Update, 9(4): 543-546.
Author for correspondence :

\section{Y.J. WAGHMODE}

Department of Extension Education, Dr. Balasaheb Sawant Konkan Krishi Vidyapeeth Dapoli, RATNAGIRI (M.S.) INDIA Email: waghmodeyogesh @ gmail.com

See end of the article for authors' affiliations 